\title{
Diversionary Foreign Policy in Authoritarian States: The Use of Multiple Diversionary Strategies by Saddam Hussein during the Gulf War
}

Kilic B. Kanat

Penn State,Erie, kbk12@psu.edu

Follow this and additional works at: https://digitalcommons.usf.edu/jss

pp. 16-32

\section{Recommended Citation}

Kanat, Kilic B.. "Diversionary Foreign Policy in Authoritarian States: The Use of Multiple Diversionary Strategies by Saddam Hussein during the Gulf War." Journal of Strategic Security 7, no. 1 (2013) : 16-32.

DOI: http://dx.doi.org/10.5038/1944-0472.7.1.2

Available at: https://digitalcommons.usf.edu/jss/vol7/iss1/3

This Article is brought to you for free and open access by the Open Access Journals at Digital Commons @ University of South Florida. It has been accepted for inclusion in Journal of Strategic Security by an authorized editor of Digital Commons @ University of South Florida. For more information, please contact digitalcommons@usf.edu. 


\title{
Diversionary Foreign Policy in Authoritarian States: The Use of Multiple Diversionary Strategies by Saddam Hussein during the Gulf War
}

\author{
Abstract \\ The diversionary theory of war has been considered one of the most contested theories that \\ link domestic and external conflicts. Thus far scholarship in this field has focused on one- \\ time single diversionary attacks, which led to the temporary deflection of attention from \\ domestic problems to external ones. This study intends to bring revisions to the \\ assumptions in the center of diversionary theory and demonstrate these through a well- \\ known but underutilized case. This article intends to show that leaders have not one single \\ option but rather a repertoire of different foreign policy actions in their possession to divert \\ the attention of domestic public. In addition to the use of force, leaders can also use the \\ threat to use force and other less violent means to create a rally round the flag effect. \\ Secondly, this study will show that, unlike the presumptions of the previous studies, leaders \\ can use multiple different diversionary strategies within a short period of time if the initial \\ diversionary action does not create intended outcomes and if they are still willing to use \\ externalization to boost his approval rating and divert public attention from present \\ problems. These two contributions to the theory will be demonstrated in the case of \\ Saddam Hussein's attacks to Kuwait and Israel during the first Gulf War.
}

This article is available in Journal of Strategic Security: https://digitalcommons.usf.edu/jss/vol7/iss1/3 


\section{Introduction}

For many years, scholars debated whether the diversionary motivations of political leaders could be a source of international conflict and warfare, and whether leaders dealing with domestic crises could resort to the use of force against external threats in order to distract the attention of the domestic public. This diversionary theory of war has frequently been suggested by opposition parties and some journalists after a leader uses force or escalates tensions against another country, particularly when the opposition feels that the action is not related to national security concerns.

This study aims to contribute to the debate on the diversionary theory of war by focusing on the use of this strategy by a non-American and non-democratic leader. The study will show that leaders can use diversionary actions short of war in addition to the use of force, and may even employ multiple forms of these strategies when they require some source of distraction to temporarily relieve themselves of domestic pressures. The article is divided into three main parts: the first will summarize the development of the diversionary theory of war; the second will focus on proposed revisions in the scholarship; and the third will provide the application of the theoretical revisions to a particular case study, namely Saddam Hussein's aggressive foreign policy against multiple countries during the Gulf Crisis.

\section{Diversionary Theory of War}

Diversionary theory of war is one of the most controversial theories of foreign policy. In its simplest form, the theory states that leaders who are facing certain domestic economic, political, and social problems at home, and who do not have immediate solutions for these problems, resort to a strategy of distracting the attention of the public away from these domestic problems to provide temporary relief. ${ }^{1}$ In most instances, the distraction succeeds when the public stops focusing on domestic problems and instead focuses on foreign policy. The primary motivation behind such an endeavor is what is sociologically known as the in-group/out-group mechanism, meaning that a conflict with an out-group usually unites the members of a particular group. Sociologists such as Simmel and Coser provided a systemic explanation of this mechanism in their studies and asserted, "war with the outside is sometimes the last chance for a state ridden with inner antagonisms to overcome these antagonisms, or else to break up definitely." "In fact, it was argued that a political leader's feelings of insecurity about his political survival may provoke his starting hostilities with an external group in order to trigger a rally effect within his own group and bolster support. ${ }^{3}$

Early systemic studies of diversionary theory of war took place in the 1960s and 1970s. However, scholars of international studies reached contradictory results about the link between domestic problems and external conflict. For instance, quantitative studies conducted during this period - to determine if there were any diversionary motivations on the part of leaders who

\footnotetext{
${ }^{1}$ Levy, in his review of the literature defined the theory as the "idea that political elites often embark on adventurous foreign policies or even resort to war in order to distract popular attention away from internal social and economic problems and consolidate their own domestic political support." Levy, Jack S., "Diversionary Theory of War: A Critique," in Manus I. Midlarsky, ed., Handbook of War Studies (London: Unwin-Hyman, 1989), 259.

${ }^{2}$ Simmel, George, Conflict (Glencoe: Free, 1955).

${ }^{3}$ Levy, Jack S. and William R. Thompson, Causes of War (Chichester: Wiley-Blackwell, 2010).
} 
launched military strikes and engaged in armed conflicts with other countries-failed to reach a substantive conclusion and, in some cases, argued that there was no meaningful link between domestic and external conflicts at all. ${ }^{4}$ However, other sociological findings and anecdotal knowledge in the field were contradictory to the findings of these studies. For example, some scholars stated that, "it appears to be a general law that human groups react to external pressure by increased coherence" and thus, "statesmen may be driven to a policy of foreign conflict—if not open war-in order to defend themselves against the onslaught of domestic enemies."

The dominant systemic determinants of external relations of nations during the Cold War years did not allow theories that focused on domestic determinants of foreign policy to flourish. However, in the last years of the Cold War, several studies began to focus on the diversionary theory of war in a more systematic fashion. One of the most significant challenges of the predominance of neorealist theories came from the works of Ostrom and Job. In their study, they found that, compared to some domestic factors, international factors were less important with regard to presidential use of force. ${ }^{6}$ This meant that while giving a decision to use force against external others, leaders could be much more influenced by their approval ratings within the country than by other more systemic and external factors. Ostrom and Job's study not only created a major debate regarding domestic versus external sources of presidential use of force, but also launched an almost separate field that focused on the use of force by American presidents. Due to several practical advantages of focusing on United States (U.S.) presidentsincluding availability of data and relative frequency of using force, especially during the terms of President Bush and President Clinton-diversionary studies began to revolve around the use of force by U.S. presidents. Throughout the 1990s, a scholarly conversation on diversionary theory of war emerged, thanks to the contribution of scholars such as James and Hristoulas, Lian and O'Neal, DeRouen, and DeRouen and Peake, the majority of which focused on presidential uses of force. ${ }^{7}$ In later years, during the post-September 11 th era, the debate on presidential use of force focused more on external determinants, such as global terrorism and weapons of mass destruction. During this period, scholarly conversation on the diversionary theory of war evolved around methodology and data, and studies focusing on diversionary uses of force by other world leaders began to emerge.

\footnotetext{
${ }^{4}$ For some of the contradictory findings regarding the diversionary motivation of political leaders, see: Burrowes, Robert and Bert Spector, "The Strength and Direction of Relationships Between Domestic and External Conflict and Cooperation: Syria, 1961-67," (New York City: Paper prepared for delivery at the Sixty-fifth meeting of the American Political Science Association, September 2-6, 1969); Jonathan Wilkenfeld, "Domestic and Foreign Conflict Behavior of Nations," Journal of Peace Research 5:1 (1968): 56-69.

${ }^{5}$ Dahrendorf, Ralf, Class and Conflict in Industrial Society (Stanford, CA: Stanford University Press,1959); Richard N. Rosecrance, Action and Reaction in World Politics; International Systems in Perspective (Boston: Little, Brown, 1963).

${ }^{6}$ Charles Ostrom and Brian L. Job, "The President and the Political Use of Force," American Political Science Review 80 (1986): 541-566.

${ }^{7}$ Patrick James and Athanasios Hristoulas, "Domestic Politics and Foreign Policy: Evaluating a Model of Crisis Activity for the United States," The Journal of Politics 56:2 (1994): 327; B. Lian and J. R. O'Neal, "Presidents, the Use of Military Force, and Public Opinion," Journal of Conflict Resolution 37:2 (1993): 277-300; Karl DeRouen, "The Indirect Link: Politics, The Economy and the Use of Force," Journal of Conflict Resolution 39 (1995): 671695; Karl DeRouen Jr. and Jeffrey Peake, "The Dynamics of Diversion: The Domestic Implications of Presidential Use of Force," International Interactions 28:2 (2002): 191-211.
} 
Although it remains difficult to prove the diversionary intentions of political leaders today, and though the field itself has increasingly focused on American presidents and presidential use of force, diversionary theory of war has significant potential to explain the uses of force and the threat to use force by non-U.S. leaders. However, the theory necessitates some revisions in order to more comprehensively explain the domestic/foreign policy nexus. Particularly since the renaissance of the scholarship on diversionary theory of war in the post-Cold War era, the studies focus predominantly on U.S. presidents and, in some exceptional circumstances, on the use of force by other democratic Western countries. This not only puts significant limitations on possible cases of study, but also creates an almost methodological discrimination against more qualitative studies, such as those based on historical accounts, anecdotal knowledge from memoirs, and secondary sources. The subsequent section of this article will demonstrate how diversionary strategy is more frequently employed in world politics than assumed and, with some "friendly amendments", this theory of war can be turned into a "a theory of foreign policy" that can be useful in understanding the sources of international conflict in other regions of the world. Before focusing on the use of diversionary strategies by Saddam Hussein during the Gulf War, this article aims to revise and refine some basic premises of the classical diversionary theory of war and rescue the theory from the traditional focus on the United States.

\section{Theoretical Reformulations}

\section{A Diversionary Theory of Foreign Policy?}

For many years, scholars investigated the diversionary motivations of leaders only when they use force against an external other. This not only created a reductionist approach in studying diversionary theory of war but also isolated diversionary theory from other foreign policy theories and approaches. This created several significant problems for the development of scholarship in this field.

First, by focusing on the motivations of leaders only during times of war and armed conflict, scholars ignored other possible strategies for leaders to use foreign policy in order to distract attention away from domestic problems. However, public opinion literature provided ample studies on the rally effect of other forms of foreign policy actions on the approval ratings of leaders, but few scholars tried to integrate the findings of these two separate fields in their studies. ${ }^{8}$ Second, this reductionist approach also lead to the assumption that a lack of armed conflict or use of force meant that the decision of the president was unrelated to his domestic approval rating or the distraction of the domestic public. The neglect of this option created difficulties in understanding the real sources of international conflict.

Many scholars in previous decades criticized this minimalist approach in diversionary studies and argued that a revision of dependent variables of diversionary theory was needed. For instance, prominent scholars of international relations, including Joe Hagan and Jack Levy, argued that leaders may sometimes resort to less risky options in order to distract the attention of

\footnotetext{
${ }^{8}$ Ann Fischback, Rivlin "The Diversionary Theory of Foreign Policy?: American Presidents and Public Opinion," Dissertation (Ann Arbor, Michigan: University of Michigan, 2008). This dissertation is a recent example of a study that takes into account diversion with cooperative foreign policy gestures.
} 
the domestic public, as a means of avoiding long and costly wars. ${ }^{9}$ For Levy, these "actions short of war are generally more cost-effective in achieving the desired internal effect than an actual war." ${ }^{\prime 10}$ Both Hagan and Levy suggested extending the scope of dependent variables in studies of diversionary theory of war in order to include other less costly and risky alternatives. Under such an interpretation, leaders could, in some instances, use the threat to use force instead of using force, or could engage in other diplomatic maneuvers, such as escalatory discourse or economic sanctions.

Hagan and Levy were not alone in targeting the scope of dependent variables in diversionary studies. Following their studies, several other scholars, including Morgan and Bickers, also stressed the need to bring a more comprehensive perspective to the scholarship on diversionary theory of war. Until these studies, none of the well-known studies in the field focused on diversionary actions short of war. In addition to lower-level hostile actions short of war, Morgan and Bickers offered other, more peaceful options that could be used to divert the attention of the public away from domestic problems. ${ }^{11}$ Although other scholars-including Richards, Morgan, Wilson, Schwebach, and Young-later examined such strategies, there remained a shortage of empirical studies that tested the possibility of these uses to achieve the same goal. ${ }^{12}$ In one of the rare studies that considered these 'more peaceful' options, Rivlin argued that, in terms of U.S. foreign policy, the president could rally the public as the commander-in-chief and also as a peacemaker or diplomatic giant. She stated:

"While scholars investigating this theory are correct that the president utilizing military troops potentially could result in a rallying of the population, they mistakenly ignore other roles the president can use to his advantage. In particular, it is possible that the position of the president as the chief diplomat and as the voice of the government to the people also can be utilized by the president to boost public opinion. Both these roles carry with them media attention and symbolic appeal and tend to be associated with non-conflictual activities such as speeches, trips, and negotiations.",13

Given that the decision to use force is a foreign-policy decision and that leaders can substitute one foreign policy option over another depending on circumstances, a modification in the dependent variable of diversionary theory of war is necessary. Otherwise, the theory will fail to answer questions raised by scholars of foreign policy substitutability, including those of Most and Starr and Bennett and Nordstrom. ${ }^{14}$ Their studies indicated that leaders have different foreign

\footnotetext{
${ }^{9}$ Joe Hagan, "Domestic Political Conflict, Issue Areas, and Some Dimensions of Foreign Policy Behavior Other than Conflict," International Interactions 12:4 (1986): 291-313.

${ }^{10}$ Jack S. Levy, "Diversionary Theory of War: A Critique," in Manus I. Midlarsky (ed.), Handbook of War Studies (London: Unwin-Hyman, 1989), 281.

${ }^{11}$ Clifton Morgan and Kenneth Bickers, "Domestic Discontent and the External Use of Force," Journal of Conflict Resolution 36 (1992): 32.

${ }^{12}$ Diana Richards, T. Clifton Morgans, Rick K. Wilson, Valerie L. Schwebach, and Garry D. Young, "Good Times, Bad Times, and the Diversionary Use of Force A Tale of Some Not-So-Free Agents," Journal of Conflict Resolution 37:3 (1993): 529.

${ }^{13}$ Rivlin, "The Diversionary Theory of Foreign Policy," 8.

${ }^{14}$ Most and Starr described this foreign policy substitutability by raising two issues. First, they argued that, "through time and across space, similar factors could be plausibly be expected to trigger different foreign policy acts," and second, "different processes could plausibly be expected to lead similar results." According to them, "if foreign
} 
policy actions at their disposal and, as such, can select any of these (depending on the circumstances and his/her cost benefit calculations) in order to reach the same goal. This would also mean that a leader could pick any of the diversionary strategies from his supply of foreign policy actions to reach the same goal of diverting the attention of the domestic public. If the single goal of the leader is diversion (assuming that the leader is a rational actor), then, in many instances, uses of force or declarations of war would not be the first option. In countries with domestic troubles especially, leaders-instead of a long, costly, and risky war that could entail many uncertainties - may prefer other alternatives and determine whether or not those actions are creating the desired result. For example, scholars of public opinion demonstrated that rhetorical escalations and foreign policy speeches can play important roles in increasing domestic support for the president and uniting the population behind him or her. These may also divert the attention of the domestic public by shifting political discussion and changing headlines for a temporary period of time. ${ }^{15}$ Considering foreign policy substitutability, the rationality of political leaders, and the availability of alternative strategies in the following case study, it will be shown that a leader can: 1) threaten to use force instead of engage in a military strike or war in order to deflect attention, and 2) revise the diversionary strategy that he/she is using if he/she believes that a previously used diversionary strategy is no longer creating the desired impact.

\section{Diversion in Countries other than the United States}

Another limitation of diversionary scholarship is the presence of American exceptionalism in the literature. As mentioned, diversionary theory, since its renaissance in the 1990s, has

predominantly focused on U.S. presidents and how U.S. presidents externalize domestic political and economic problems through the use of force against other countries. Availability of quantitative data regarding presidential approval ratings and economic statistics, together with the use of force by U.S. president in these years, have made scholars in the field to focus more on presidential uses of force Due to burgeoning studies in the field, many scholars have begun to consider that the use of diversionary strategies is very much at the disposal of American presidents. ${ }^{16}$ According to Fordham, for example, the use of diversionary strategies is not a universal way of dealing with domestic problems; it is a particularity of the U.S. presidency. ${ }^{17}$

Other than the availability of data and broadness of cases, what lead to this idea of "American exceptionalism" in the field was partly a result of the main assumptions of diversionary theory of war. In its original form, the leader who can engender the violent externalization of a domestic

policies can indeed be alternative routes by which decision makers attain their goals, then it would seem plausible that decision makers who are confronted with some problem or subjected to some stimulus could, under at least certain conditions, substitute one such means for another"; Benjamin A. Most and Harvey Starr, Inquiry, Logic, and International Politics (Columbia: University South Carolina Press, 1989); Also see D. Scott Bennet and Timothy Nordstrom, "Foreign Policy Substitutability and Internal Economic Problems in Enduring Rivalries," Journal of Conflict Resolution 44:1 (2000): 33.

${ }^{15}$ For examples of these findings, see Michael MacKuen, "Political Drama, Economic Conditions, and the Dynamics of Presidential Popularity," American Journal of Political Science 27 (1983): 165-192; Robin Marra, Charles W. Ostrom, and Dennis M. Simon, "Foreign Policy and Presidential Popularity Creating Windows of Opportunity in the Perpetual Election," Journal of Conflict Resolution 34:4 (1990): 588-623; Brace, Paul and Barbara Hinckley, Follow the Leader: Opinion Polls and the Modern Presidents (New York: Basic Books, 1992).

${ }^{16}$ Benjamin O. Fordham, "Another Look at 'Parties, Voters, and the Use of Force Abroad," Journal of Conflict Resolution 46.4 (2002): 572-596.

${ }^{17}$ Benjamin O. Fordham, "Strategic Conflict Avoidance and the Diversionary Use of Force," The Journal of Politics 67 (2005): 132-153. 
conflict, without worsening domestic political and economic conditions, requires a powerful military. The results of an external strike need to be more or less foreseen by the leader, since the defeat of its forces may endanger the sovereignty of the country, and prolongation of war could worsen the leader's domestic situation. Under these conditions, only the leaders of great powers seem to have the capability and opportunity to use force for diversionary purposes. This assumption, however, ignores the availability of alternative, less costly and risky strategies that the leader can utilize. Given the coincidence of the rise of diversionary scholarship in the 1990s with the unipolar international system-in which the U.S. is considered the sole global political, economic, and military power capable of projecting power in different parts of the world-the U.S. is deemed the only country that can execute such actions and bear the consequences (if any are to result). The Iraq War in 1991 demonstrated that, because of the revolution in military affairs, the U.S. was the only country capable of winning a short and decisive battle by means of its superior military capabilities, and in particular its air force. Thus, under these assumptions, U.S. presidents would be the only leaders capable of benefiting from a diversionary use of force without creating more political troubles domestically.

A second argument for American preeminence in diversionary scholarship was an assumption regarding the relationship between regime type and expression of diversionary behavior. Although early studies in diversionary theory never differentiated between societies and regimes and their use of diversionary strategies, several scholars later began to focus on regime type as a significant determinant for these strategies. The predominant idea was that authoritarian leaders, due to their unlimited power and ability to suppress opposition against their regimes by use of force, would not need to use alternative manners of dealing with domestic problems and as a result, wouldn't need to use diversionary strategies. Democratic leaders, on the other hand, were vulnerable to domestic opposition, since they 1) could not suppress the opposition as they wished, and 2) had electoral concerns. As a result, democratic leaders would search for options to distract public attention away from domestic problems and gain time-while the public was focusing on an external problem-to handle or resolve domestic problems. ${ }^{18}$ In fact, as stated by scholars like Clark, Fordham, and Nordstrom:

"Democratic leaders are usually held to have fewer options than their authoritarian counterparts for dealing with unhappy citizens since autocrats can often repress, or control information in such a way that citizens do not necessarily blame the government for poor domestic circumstances. Further, democratic leaders are often presumed to have more autonomous control over foreign policy and the military than over domestic policy tools. In this light, it is not surprising that Gelpi goes so far as to call diversionary foreign policy "a pathology of democratic systems," suggesting democratic leaders will succumb to the temptation of international violence when domestic trouble is brewing.",

This interpretation leads many in the field to ignore cases when authoritarian regimes use diversionary strategies, and instead focus on democratic countries. Alongside the initial assumption regarding military might, this theory on the regime type/diversionary strategy

\footnotetext{
${ }^{18}$ Christopher Gelpi, "Democratic Diversions Governmental Structure and the Externalization of Domestic Conflict," Journal of Conflict Resolution 41:2 (1997): 255-282.

${ }^{19}$ David Clark, Benjamin O. Fordham, and Timothy Nordstrom, "Preying on the Misfortune of Others: When Do States Exploit Their Opponents' Domestic Troubles,” Journal of Politics 73:1 (2011): 252.
} 
relation has, in fact, reinforced U.S. exceptionalism in diversionary theory of war. It is in some sense ironic that - despite significant cases of diversionary theory of war, such as the diversionary war launched by the Argentinian junta against Britain in the Falklands Islands and the Russian declaration of war against Japan in 1905- since the 1990s, even the possibility of use of force by authoritarian leaders has not been taken into consideration.

Both of these assumptions portraying presidential use of force as strategically exceptional can be challenged. First, although American military power can be a significant factor in presidential uses of force, the availability of other, less risky and costly options makes it possible for leaders of other countries to utilize these strategies as well. As such, leaders of less prosperous countries with smaller armies could also employ less costly strategies and, instead of using force, could utilize some rhetorical assault against other countries to deflect the attention of domestic public. In addition, despite claims about the relationship between regime-type and use of diversionary strategies, studies on authoritarian regimes demonstrate that dictators are also sensitive to public opinion and try to know and follow what the public thinks about their actions. Moreover, although there are no elections in authoritarian regimes, leaders in these countries still have certain constituencies that they must take into account. In most instances, these are powerful stakeholders in the regime, such as politburo members and/or the military. Furthermore, studies demonstrate that most authoritarian leaders know that using force is not a viable long-term option, and thus need to determine complementing strategies to stay in power. As Kneur and others argue, using foreign policy is one of these options. ${ }^{20}$

To sum up, as scholars like Weeks have emphasized, "[A] utocratic leaders, while they may exert enormous control over their subjects, are not usually immune from domestic threats to their tenure," and "most authoritarian leaders require the support of domestic elites, who act as audiences in much the same way as voting publics in democracies." ${ }^{21}$ In fact, some authoritarian leaders can be more vulnerable and dependent on the support of domestic audiences than is commonly assumed. When they experience this vulnerability, shifting the focus to foreign policy becomes a viable option.

The literature is full of examples of authoritarian leaders using foreign policy for domestic purposes. Studies by historians and area studies experts on the Middle East, in particular, reveal several instances of leaders manipulating a foreign policy-related event in order to retain legitimacy and improve their standing in the country. ${ }^{22}$ Scholars, including Tessler and Grobschmidt and Perthes suggest that leaders in the Middle East utilize external threat and

\footnotetext{
${ }^{20}$ Kneur, Marianne, The Quest of Legitimacy: Foreign Policy as a Legitimation Strategy in Authoritarian Regimes (Sao Paulo: ISPA and ECPR Joint Conference, February 16-19, 2011).

${ }^{21}$ Weeks, Jessica L., "Leaders, Accountability and Foreign Policy in Non-Democracies" Dissertation (Stanford, CA: Stanford University, 2009).

${ }^{22}$ For instance, Seale argues that Hafiz al-Assad of Syria also had concerns regarding the power of public opinion. According to Seale, Assad's rule was not based on force alone, nor would it have survived had it been so. The factor of public approval was not negligible; in fact, Arab regimes such as his, so often derided as oriental despotisms, required a measure of popular consent. The importance of public opinion could be gauged by the strenuous efforts made to mobilize popular consent, by repeated exercises in public self-justification, and by strident media campaigns which rival Arab states waged against one another. Both the leaders and the led understood that once popular consent was withdrawn, the regime's power diminished. Seale, Patrick. Asad of Syria: the Struggle for the Middle East (Berkeley, CA: University of California, 1988), 178.
} 
national security concerns in order to deflect attention away from domestic problems. ${ }^{23}$ According to them, this maneuver has become a survival strategy for leaders in the region who face significant domestic political and economic challenges, and has been constantly and, in most instances successfully, utilized. Most of these accounts occur in presidential biographies, historical accounts, and memoirs. However, acquiring resources from such secondary sources necessitates a dialogue between diplomatic history, area studies, and scholarship on diversionary theory of war. As such, the following case study of Saddam Hussein's use of diversionary strategies against other countries integrates the findings of diplomatic historians, area specialists, and diversionary scholars. Historical studies about the Gulf War and Saddam Hussein's decisionmaking during the conflict demonstrate that the current, data-driven nature of scholarship is partly responsible for the predominance of U.S. presidential action in the field. It is possible to overcome this problem, however, by effective use of data from other research mechanisms.

\section{The Gulf War and Saddam Hussein's use of Diversionary Strategies}

The First Gulf War (following the invasion of Kuwait by Iraqi forces) and Saddam Hussein's subsequent foreign policymaking provides an excellent case study to observe the diversionary foreign policy of a non-American, authoritarian leader facing significant domestic economic and political hardships. Iraqi foreign policy in the period between the end of Iran-Iraq War and the end of the Gulf War provides significant insight into the manner in which leaders can resort to multiple diversionary strategies. During these years, Iraq faced significant economic, political, and social challenges, and the government in Baghdad was, in most instances, incapable of responding to the people's economic and political demands. Considering these difficulties, Saddam Hussein's regime began utilizing diversionary strategies in order to temporarily divert the domestic public's attention away from these problems. The rhetorical diversion that was launched by Saddam Hussein against the Gulf countries, Israel, and the West gradually turned into a diversionary use of force. In addition to the evolution of diversionary strategies, the target of diversionary strategy was also different: in more advanced stages of diversionary strategy, Saddam Hussein attempted to mobilize Arab nations as well as the Iraqi public. Although some diplomatic historians and experts of Iraqi politics documented these strategies without using the "diversionary theory of war," most of Saddam's policies fit very nicely within diversionary foreign policy. As such, the case demonstrates possible extensions of the dependent variable of studies on diversionary theory of war.

Diversionary strategies are usually employed by political leaders of countries facing serious domestic problems, and in 1990, Iraq was facing many such problems. The economy of the country in particular was in ruins after the eight-year, extremely costly battle with Iran. The war devastated the normal functioning of the economy and created a major external debt problem, and bombings by the Iranian air force to Iraq's industrial centers destroyed industry and infrastructure in the country. Not only did external debtors begin pressuring the Iraqi government to return their loans, but Iraqi citizens were also waiting for the economic rewards that Saddam

\footnotetext{
${ }^{23}$ Mark Tessler and Marilyn Grobschmidt, "Democracy in the Arab World and the Arab-Israeli Conflict," Democracy, War and Peace in the Middle East (Bloomington: Indiana UP, 1995), 144; Volker Perthes, "Si Vis Stabilitatem, Para Bellum: State Building, National Security, and War Preparation in Syria," in Steven Heydemann, (ed.), War, Institutions, and Social Change in the Middle East (Berkeley, CA: University of California Press, 2000), 149-173, 159.
} 
Hussein had promised over the course of those eight years. Negotiations for additional funds and efforts to reform the economy failed miserably in the last years of the 1980s. The rapid increase in unemployment after the demobilization of part of the Iraqi military was particularly concerning.

Economic problems also brought with them significant social problems. The economic reforms gave rise to black markets, and high increases in price fueled social anger towards the government. The formation of small-scale demonstrations in Baghdad demonstrated how social resentment began to surpass the fear threshold among the Iraqi public and illustrated the first such reaction against Saddam Hussein after he assumed power. In addition, Shia groups in the south of the country, which constituted more than 60 percent of the population, and Kurdish insurgence in the north continued to constitute a major threat for the country's political stability and territorial integrity. Furthermore, the international atmosphere did nothing to help Saddam Hussein. It was a sensitive time for authoritarian regimes worldwide, due to the end of the Cold War and the fall of communist totalitarian and authoritarian regimes in Central and Eastern Europe, most of which had been natural allies of the Iraqi regime for decades. In particular, the overthrow and public execution of Nicolae Ceausescu created major concerns among authoritarian rulers in the Middle East. Following the event, Saddam Hussein asked his security officials to study the case in Romania to avoid similar consequences in Iraq.

According to scholars like Chaudhry, the situation in Iraq in 1990 was so grave that "not even the experienced repressive apparatus of the Ba' ath Party could guarantee domestic political stability." ${ }^{24}$ In addition to demonstrations and increasing levels of social unrest, Saddam Hussein also began being challenged by people within his own inner circle. For the first time in his presidency, Saddam Hussein faced three assassination attempts between the end of the war with Iran and the Gulf Crisis. ${ }^{25}$

Saddam Hussein knew that there was no quick fix to the problems he encountered.

Reconstruction after the war, economic reforms, and social stability would take significant time, and resentment against his rule was growing steadily. In the midst of these difficulties, he had two options: either suppress the opposition within the country and use an iron fist to silence social resentment, or divert the attention of the domestic public. Although he successfully implemented this strategy numerous times-contributing to his moniker as the "strong man of Baghdad"- - his previous experience during the pre-Bath period made him recognize that suppression could, in some instances, backfire and create further resistance to his rule. Bath resistance against the Iraqi regime survived, despite suppression and political repression for decades, and ultimately led to an overthrow of power. In fact, as stated by Karsh and Rautsi:

"It had been evident to him, from early on, that even the least democratic form of government required substantial popular support... He knew that a regime ruling

\footnotetext{
${ }^{24}$ Kiren Aziz Chaudhry, "On the Way to Market: Economic Liberalization and Iraq's Invasion of Kuwait," Middle East Research and Information Project, 1991, available at: http://www.merip.org/mer/mer170/waymarket?ip_login_no_cache=4decc7b4d9cff6413076262a4ed07b74.

${ }^{25}$ Freedman, Lawrence and Efraim Karsh, The Gulf Conflict: 1990-1991: Diplomacy and War in the New World Order (London: Faber and Faber, 1993), 29-30.
} 
at the points of bayonets was condemned to a precarious existence, and bound to come to an abrupt end."26

Because of this, Hussein required an alternative that could be periodically substituted with repression.

This second option was to temporarily divert the attention of the domestic public and create a 'rally around the flag' effect. Shifting the attention of the domestic public away from domestic economic and social problems would allow him time to either consolidate his rule and suppress more efficiently, or find a resolution to the problem. In both instances, however, he would be able to save face against domestic pressures. The issue that he would use as a diversionary tool could distract the public attention and make them delay or forget their "less existential" demands and objections. In an artificially manufactured external crisis, Saddam Hussein would have a chance to ask for further sacrifice and generosity from his people, while unifying them for a single goal.

Like other Middle Eastern leaders, Saddam Hussein also used these diversionary mechanisms during his political career. He frequently utilized a foreign policy event or issue to either legitimize his purge campaigns and unify Iraqi society behind him, or divert the society's attention away from domestic problems. According to Karsh and Rautsi, this strategy provided "an outlet for frustration." ${ }^{27}$ In most instances, this strategy worked in Hussein's favor and helped him consolidate his power in Iraq.

When domestic problems started to emerge in Iraq in 1990, Saddam once again began to employ diversionary strategies. After the failure of the economic reforms, Saddam turned to external factors to offer reasons for the domestic problems. Such scapegoating was frequently used throughout the Iran-Iraq War. As of the 1990s, the most important source of Iraq's economic problems, according to Saddam, was not the war or the failure of his economic policies, but the Kuwaiti government and its policies. For Saddam, Kuwait was waging an economic war against the Iraqi government with the intention of destroying it. Although scholars of diversionary studies neglect this incident in their research, scholars of Iraqi politics indicate that Saddam's increasingly harsh discourse towards Kuwait and Gulf sheikdoms was an attempt to deflect the Iraqi people's attention from the country's domestic problems. According to Long, for example, under difficult domestic economic and political challenges, Saddam started to look for an exterior crisis with which to replace the war in Iran. This crisis would, on the one hand, divert the attention away from these domestic problems and, on the other hand, justify the continuation of active military service in the country. As a result, Saddam could incite compliance for yet another existential external threat to the survival of his country. ${ }^{28}$ Kuwait provided an excellent opportunity for Saddam Hussein and a very effective source of diversion. Karsh and Rautsi, historians of the Gulf War, make note of Saddam's intention to scapegoat Kuwait in their studies. According to them:

\footnotetext{
${ }^{26}$ Karsh, Efraim and Inari Rautsi, Saddam Hussein A Political Biography (New York: Grove, 2002), 89.

${ }^{27}$ Ibid, 57.

${ }^{28}$ Long, Jerry M. Saddam's War of Words: Politics, Religion, and the Iraqi Invasion of Kuwait (Austin: University of Texas, 2004), 13.
} 
"In the summer of 1988 Iran was debilitated; Iraq's military power was greater than ever, having steadily expanded during the war. In Tehran an agonizing reckoning was already under way; in Baghdad millions were dancing on the streets.

Yet not even such euphoric circumstances would lure a professional survivor like Hussein into a false sense of security. He had no illusions, whatsoever, realizing that the celebrations would give way to a hangover; that a bill for the dislocations of the war would be presented in one form or another. He knew that even in the most repressive police state there are limits to what people are willing to endure or the sacrifices they are prepared to make. The removal of the Iranian threat, the main factor cementing Iraqi society during the war years, generated an urgent need for new means of rallying public support and enthusiasm behind Saddam., ${ }^{29}$

It is not very easy for leaders to mobilize their societies against an external enemy in the absence of any social and political resentment towards that country; instead, the externalization works when the society is ready to rally behind the leader due to the existence of previously formed anger towards another state. Kuwait, at the beginning of the Gulf War, was a state that could serve Saddam's diversionary purposes. There had already been historical conflict between Kuwait and Iraq, ever since the emergence of the independent state of Kuwait. Former leaders of the country, prior to Saddam Hussein, had claimed that Kuwait actually belonged to Iraq. The source of the claim was the historical boundaries established during the Ottoman Empire. By then, the territories of Kuwait were within the Basra province, and because the Basra province became one of the three provinces that formed Iraq, Kuwait's standing as territory carved from Basra created resentment among the Iraqi people. Moreover, there were several other territorial conflicts between Iraq and Kuwait, which included the Rumaliyah oilfields and the Bubiyan and Warbah islands. Furthermore, the economic stability and richness of the Gulf States, including Kuwait, had always been a source of resentment among other Arab countries. All of these conditions made it easy for Saddam Hussein to mobilize his people against Kuwait.

There was a problem, however, for Saddam Hussein's use of Kuwait as a diversionary target. Despite existing resentment in some segments of Iraqi society against Kuwait, it would be highly improper for a leader like Saddam Hussein, who had claims for potential leadership of the Arab world, to attack to a weaker Arab state. This would greatly tarnish his image as a leader of panArabism, who fought eight years against Iran in order to protect the spread of Iranian revolutionarism to other Arab countries, and be considered a betrayal of the non-aggression norms of the Arab League. Although the Iraqi people may have welcomed such a rhetorical escalation, Arabs in other parts of the Middle East may have perceived the action differently.

Considering these impediments and possibilities, Saddam attempted to link the conflict in Kuwait to a more Arab-wide struggle. An escalation with Kuwait could only rally the Iraqi public, but a rhetorical escalation toward Western powers could mobilize broader Arab support. As a result, Saddam Hussein, in the very early days of the Gulf Crisis, began to link the bilateral tensions between Iraq and Kuwait to an external plot to overthrow the government and destroy Iraq. Saddam claimed that problems in the Iraqi economy, which were seemingly domestic in

\footnotetext{
${ }^{29}$ Karsh and Rautsi, Saddam Hussein A Political Biography, 194.
} 
nature, were related to schemes by external forces. ${ }^{30}$ Although Kuwait was waging an economic war against Iraq, it was ultimately a tool of the enemy imperialist forces to destroy the country as a whole.

An early indication of Saddam Hussein's intention to use this strategy were his speeches delivered throughout the 1990s. He constantly highlighted threats from outside forces to the security of the Arab world and especially preferred to use regional forums in order to relay his message. Saddam Hussein always believed that rhetorical escalation towards the "others" of the Middle East could serve as an excellent method of mobilizing Arab nations, building stature, and diverting attention away from other problems. Depending on the context, these "others" include Iran, Israel, and Western countries. Such rhetorical attacks were widely publicized among the Arab people in the Middle East and, in some instances, provided high esteem and support for Saddam Hussein.

While using this assertive and aggressive discourse, however, Saddam was also trying to prevent backlash from Western countries and reassure them that these maneuvers were carried out only for domestic consumption. In particular, he tried to reassure decision-makers in Washington about the domestic nature of his speeches. ${ }^{31}$ An important account of this strategy reportedly took place during his meeting with Prince Bandar after his speech against Israel. According to Bob Woodward, in responding to question from Prince Bandar, Saddam Hussein explained the nature of the speech in the following manner:

"...[Y] ou must understand the context in which it had been made... it had been delivered to members of the armed forces at a public forum where emotions were running high, with people clapping and screaming. As we both know, it never hurts in the Arab world to threaten Israel, so I had done it." 32

In this way, Saddam was ensuring that Washington understood that he had no intention of attacking Israel:

"I want to assure President Bush and His Majesty King Fahd that I will not attack Israel" Saddam stressed..."Do you want us to mention this to Bush as our observation?" Bandar asked, "Or is it a message from you to President Bush?" "It's a message from me to President Bush" Saddam replied. ${ }^{33}$

In the same conversation, after a pause, he once again turned back to Bandar's question about his speech against Israel:

"Saddam then turned to justifying his verbal assaults on Israel, though he continued giving assurances that he would not attack the Jewish state. Israel was the natural lightning rod for creating a crisis atmosphere, he said. It had been two

\footnotetext{
${ }^{30}$ Hussein, Saddam and Salomon Ruysdael, Speeches of Deception: Selected Speeches of Saddam Hussein : A Story of Propaganda Which Began in Kuwait 10 Years Ago Today Is Not Over (New York: Writers Club, 2003 ), xviii.

${ }^{31}$ Freedman and Karsh, The Gulf Conflict: 1990-1991, 32-33.

${ }^{32}$ Woodward, Bob, The Commanders (New York: Simon \& Schuster, 1991), 210.

${ }^{33}$ Ibid, 202.
} 
years since the Iran-Iraq cease-fire, and the Iraqi people were getting relaxed. "I must whip them into a sort of frenzy or emotional mobilization so they will be ready for whatever may happen." 34

Although there is no way to confirm the accuracy of this account, it still demonstrates how diversionary foreign policy (short of war) could be utilized by the leaders of authoritarian countries. Saddam Hussein, while assuring his Western counterparts about the domestic nature of his speeches, was continuing and even escalating this tone throughout the 1990s.

In the meantime, the confrontation between Iraq and Kuwait was reaching a tipping point. Saddam Hussein frequently linked his rhetorical escalation to the crisis between the two countries, in order to gain the support of the Arab people. Much to the surprise of many in the region, on August 1, 1990, Iraqi forces invaded Kuwait. According to Coughlin, though Hussein did not expect any plaudits for his move, neither did he expect such large-scale international reaction to the invasion. After his meeting with April Glaspie, the ambassador of the United States in Baghdad, Saddam Hussein sensed invading Kuwait would not be a problem. However, a few days after invasion, the U.S. and Soviet Union issued a joint declaration of condemnation of the move. Subsequently, the United Nations Security Council convened and passed a resolution condemning the invasion and demanded the immediate withdrawal of Iraqi troops. Meanwhile, the Saudi regime accepted the United States' offer to protect Saudi Arabia from a possible Iraqi attack, and an international coalition began to form under the leadership of the United States. Saddam Hussein suddenly and unintentionally caused the West to deploy hundreds of thousands of troops to the Arabian Peninsula for the first time in decades.

Saddam Hussein was additionally shaken by the resolutions of the Arab League and the Gulf Cooperation Council condemning Iraqi actions, as his leadership claim to the Arab world had been irreparably damaged. Worsening his status further, the Arab League passed another resolution - the first ever resolution of its kind-allowing for the dispatch of troops as part of the multinational force. The Arab League summit revealed the increasing isolation of Hussein's regime from the Arab regional order. Saddam's only hope was to mobilize the Arab masses against their governments' support for the anti-Iraq international coalition. Through this strategy, he expected Arab citizens to pressure their governments into withdrawing their forces, or even overthrow them. To achieve this, Saddam escalated his diversionary strategy so that Israel and Western countries would receive more attention, simultaneously trying to divert the attention of the Arab public away from his invasion of Kuwait. In fact, as stated by Karsh and Rautsi:

"With the summit revealing an unbridgeable gap with other Arab regimes, Saddam sought to undermine them by rallying masses behind his cause by Zionizing the crisis. By linking his Kuwaiti venture to the Palestinian problem, he hoped to portray himself as the champion of the Pan-Arab cause, thereby eradicating any conceivable opposition to his move in the Arab world. If the 'restoration of Kuwait to the motherland' was the first step towards 'the liberation of Jerusalem', how could any Arab leader be opposed to it? The aggressor would be transformed into a liberator and a hero." 35

\footnotetext{
${ }^{34}$ Ibid.

${ }^{35}$ Karsh and Rautsi, Saddam Hussein A Political Biography, 100.
} 
A declaration of war against Israel by Iraq was unrealistic in 1990. After the eight-year war with Iran and an economy in ruins, Saddam Hussein likely understood that starting another costly and possibly long war with Israel was not in his best interest. As a result, Saddam instead tried to link the emerging international coalition in Saudi Arabia to the state of Israel. For instance, he suggested that Israeli pilots, disguised as Americans, had been deployed in Saudi Arabia. Although coalition forces and Saudi officials denied this accusation, Saddam Hussein continued his allegations about Israeli contributions to the war efforts. ${ }^{36}$

Possibly the most significant attempt to redirect attention away from the invasion of Kuwait to the Arab-Israeli conflict came on August 12th, with the formal initiation of linkage politics. Saddam's initial statements against Israel and Western forces struck a chord among the Arab people and more strongly highlighted the issue of the Arab-Israeli conflict. Amid international and regional pressures to withdraw from Kuwait, Saddam Hussein initiated a new diversionary maneuver by proposing a withdrawal plan — a three-point peace initiative — that primarily aimed at linking the invasion of Kuwait to other conflicts in the region and purported to "solve" all problems of territorial disputes:

"I propose that all issues of occupation in the region, and that which had been misrepresented as occupation, be solved in accordance with the same standard, principles, and premises laid down by the UN Security Council...First, to make ready withdrawal arrangements according to the same principles for the immediate unconditional withdrawal of Israel from the occupied Arab territories in Palestine, Syria, and Lebanon, and for the Syrian withdrawal from Lebanon, and for the withdrawal of troops on the Iraq-Iran front, and to make arrangements for the status of Kuwait."

While the White House and other capitals promptly rejected the proposal as an attempt to shift attention, the reaction among Arabs was more ambivalent. For some, including certain segments of Palestinians, the proposal was extremely appealing. ${ }^{38}$ In several different Arab capitals, demonstrations were organized as a show of support for the proposal, which transformed into support for Saddam Hussein.

After witnessing early signs of this support, Saddam began referencing Palestine in his addresses and invited Yasser Arafat to Baghdad to meet and extend support for the Palestinian cause. Despite his insistence on the use of diversionary messages, however, demonstrations did not evolve into popular revolutions to overthrow Arab leaders and stop their support for the international coalition. In November 1990, the UN Security Council passed another resolution, giving Iraq a withdrawal deadline of January 15, 1991, and in the event of defiance, authorized all necessary means to implement Resolution 660.

\footnotetext{
${ }^{36}$ Ibid, 101.

${ }^{37}$ Hussein and Ruysdael, Speeches of Deception: Selected Speeches of Saddam Hussein.

${ }^{38}$ Hiro, Dilip, Desert Shield to Desert Storm: The Second Gulf War (Lincoln, iUniverse, 1992), 274. This specific comment is a cited reference from Alan Brinkley as found in Dilip Hiro's book.
} 
Following the resolution, Saddam Hussein intensified his references to Palestine and Jerusalem. In his famous speech, "Mother of All Battles," he stated:

"Then the door will be wide open for the liberation of beloved Palestine, Lebanon, and the Golan. The Jerusalem and the Dome of the Rock will be released from the bondage." 39

The speech was made several days before the withdrawal deadline. Following these statements, Saddam, in a final attempt to divert the attention to the Arab-Israeli conflict, attacked Israel using SCUD missiles. This was a revision of rhetorical diversion to a more action-based diversionary strategy. Instead of threatening to use force, Saddam began actively using force to reach the same goal. He also already knew that there would be no retaliation from Israel, and that the attacks were expected to be conducted from Saudi territory. Moreover, striking Israel would not bring any strategic military advantage to Iraq. However, Saddam Hussein was aware of possible subsequent support of the action from the Arab masses.

Diplomatic historians and experts on Iraqi politics interpreted the attacks as diversionary in nature. For instance, Jerrold Post evaluated Hussein's policies during the Gulf War in the following way:

"What began as an act of naked aggression toward Kuwait was transformed into the defining drama of his life. Although he had previously showed little concern for Palestinian people, the shrewdly manipulative Saddam had wrapped himself and his invasion of Kuwait in the Palestinian Flag." 40

For James Piscatori on the other hand, the broader goal was not only to mobilize the Iraqi people or the Arab masses, but the whole of the Muslim world. According to him:

"When Saddam Hussein launched his initiative of August 12th explicitly linking his withdrawal from Kuwait with Israeli withdrawal from the occupied territories, he was exploiting the profound sentiment that had become the Arab-and the Muslim-consensus. It was on one level, an obvious political ploy, a cost free way of attempting to divert attention. He appeared to strike a blow for Palestinian liberation without doing a great deal to accomplish it. But by explicitly shifting focus to the Arab-Israeli conflict and restoring the question of Palestine to pride of place, he was on another level, tapping into deep springs of Muslim concern."

Through the use of these different mechanisms, Saddam Hussein demonstrated that diversionary foreign policy is not a sole maneuver, but can be revised and modified according to the circumstances. He used multiple diversionary strategies over a short period of time and escalated the tone of diversionary rhetoric or action when he deemed it necessary.

\footnotetext{
${ }^{39}$ Hussein and Ruysdael, Speeches of Deception: Selected Speeches of Saddam Hussein.

${ }^{40}$ Jerrold M. Post, and Amatzia Baram, "Saddam Is Iraq: Iraq Is Saddam," USAF Counterproliferation Center, The Counter Proliferation Papers: Future War Series 17 (2002): 182

${ }^{41}$ James Piscatori, "Religion and Realpolitik: Islamic Responses to the Gulf War," Bulletin of the American Academy of Arts and Sciences 45:1 (1991): 17-39, 22.
} 


\section{Alternative Explanations?}

Although there is a general consensus among scholars of Iraqi politics that Saddam Hussein's Gulf War policies were intended to divert the attention of the Arab public and rally them around his leadership, there are alternative explanations for Saddam's actions offered by some. One of the most popular explanations pertains to Saddam's intention of genuinely becoming the new Saladin of the Arab world. ${ }^{42}$ This explanation, however, misses an important point about the capability of the Iraqi government after its eight-year war in Iran and the situation of Iraqi economy, which demonstrate that the country could not afford another costly war. In addition, Saddam's politics were not greatly concerned with the Palestinian issue, as the Iranian threat was most critical to Iraqi security. In previous conflicts between Arabs and Israelis, the Iraqi government did not provide active support for the warring Arab countries. During the 1973 War, for example, Iraq was only marginally involved and sent a symbolic number of troops to the Syria-Israel border. This policy of conflict avoidance created a major rift between Syria and Iraq. As a result, Bashar al-Assad refused to support Iraq during the Iran-Iraq war and claimed that war with Iran would not only damage the anti-Israeli bloc in the Middle East, but also divert Arab resources away from the more imminent threat—a Israel.

Moreover, although Yasser Arafat was invited to Baghdad and provided support for Saddam Hussein, Saddam had never been on good terms with the Palestinian Liberation Organization (PLO) and its leaders. During the "Black September", for example, he did not want to intervene in Jordan to help Palestinian refugees. Further, during the oil boom years when the Iraqi economy was growing, he excluded Palestinians from coming to work in Iraq. ${ }^{43}$ In most of the 1980s, Saddam supported Abu Nidal, who had allegedly assassinated important PLO leaders such as Abu Iyad. ${ }^{44}$ Due to this political history, Saddam's policies regarding Palestine during the Gulf War likely only had diversionary goals.

\section{Conclusion}

The diversionary theory of war has been one of the most debated theories in the interactions of domestic politics and foreign policy. This study intended to extend the scope of the theory to include different forms of diversionary strategies by a non-American leader, as well as instances where a single leader uses multiple divisionary strategies over a short period of time. It also aimed to revise the diversionary theory of war, rescue it from the constraints of the use of force, and integrate it with different theories on the public opinion and foreign policy nexus.

As discussed, Saddam Hussein's use of diversionary strategies during the Gulf Crisis provides important insights into the politics of the Middle East and the diversionary theory of war. Saddam Hussein's use of diversionary strategies demonstrates that leaders of states other than the U.S. are also able to employ maneuvers to deflect public attention away from domestic problems. Although the existence of a powerful army and sufficient economic resources may

\footnotetext{
${ }^{42}$ Erwin Randolph Parson, “The Psychology of the Persian Gulf War - Part 1 Gulf-Nam and Saddam Hussein's Nebuchadnezzar Imperial Complex: A Political Psychological Analysis," Journal of Contemporary Psychotherapy 21:1 (Spring 1991): 25-52.

${ }^{43}$ Karsh and Rautsi, Saddam Hussein A Political Biography.

${ }^{44}$ Philliph Mattar. “The PLO and the Gulf Crisis,” Middle East Journal 48:1 (1994): 31-46.
} 
provide a comparative advantage to leaders of great powers in using diversionary war and military strikes, the availability of less costly and less risky diversionary options allows leaders of other states to employ these strategies as well. In the case of the Gulf Crisis, the relative success of rhetorical diversion illustrates that the threat to use force can also have a rallying effect on a society.

Saddam's success also demonstrates that not only elected democratic officials, but also authoritarian leaders can employ these strategies. Although Saddam Hussein had total control of all coercive mechanisms of the state to suppress or punish oppositional movements, he still believed that it was vital to ensure the support of the people in order to effectively remain in power. As a result, he attempted to maintain the support of the Iraqi people as well as the Arab masses active to his war efforts.

Finally, the case of Saddam Hussein's use of multiple diversionary strategies demonstrates that leaders pay attention to incoming information, evaluate different options, and subsequently select the appropriate diversionary foreign policy. When leaders employ diversionary strategies, they prefer to follow the reactions of the public and shape their diversionary tactics in accordance with these reactions, and they are able to modify and revise their strategies after evaluating positive or negative attitudes toward these policies. Saddam Hussein, for example, gradually intensified his tone as a result of the relative success of his actions. As he observed the Arab people beginning to oppose the policies of their own governments and launch campaigns to stop their governments' support of the U.S.-led international coalition, he maintained, and even intensified, his attacks against Israel.

Together, these findings demonstrate that the diversionary use of foreign policy is not a particularity of U.S. foreign policy but is, in a broader sense, a theory of domestic politics and foreign policy interaction. The availability of less costly diversionary strategies for political leaders shows that leaders of less resourceful countries may also employ this strategy when they confront domestic problems. Moreover, depending on the level of support that they create, leaders may utilize multiple strategies gradually or at the same time. These findings offer an important approach for future studies regarding diversionary foreign policy in non-U.S. countries. 